\title{
The Importance of Environmental Materials in Learning Indonesian Language atSchool
}

\author{
Wiwi Noveria Husna. A 18016095 \\ Universitas Negeri Padang-FBS \\ wiwinoveria@gmail.com
}

Humans can not be separated from environmental problems. This is in line with Nazarenko (in Ramadhan, Sukma, and Indriani, 2019), which stated that humans will always face environmental problems. Every human being in the world must experience environmental problems such as floods, forest fires, air pollution, and so on. The damage must have been caused by humans, then human life in the present and in the future. Environmental damage not only affects natural resources, but also human resources, such as economic problems that will occur later. humans must be able to handle it.

What can be done to overcome environmental problems is to instill awareness from an early age of the importance of protecting the environment so that the environment does not suffer damage. So, this certainly cannot be separated from the environmental education implemented in schools. According to Ramadhan, Sukma, and Indriani (2019), environmental education aims to invite students to participate in protecting the environment. In line with that, according to Ramadhan, Indriyani, Asri, and Sukma, (2020), the purpose of environmental education is to provide students with a positive view on how to respond to the environment well, and increase knowledge of nature so that students understand how to be ethical towards the environment.

Environmental education can be applied in learning in schools, especially learning Indonesian. This is in line with Ramadhan, Sukma, and Indriani (2019), which state that Indonesian language teachers are the luckiest teachers of other subjects, because Indonesian language teachers can increase students' reading interest, including on environmental issues. Thus, environmental damage can be anticipated from the age of the children. 
Learning Indonesian cannot be separated from language skills, one of which is writing skills. Writing is the most important skill in education, but writing skill is a difficult skill, compared to other language skills. According to Ramadhan, Indriyani, Asri,

and Sukma, (2020), writing skills are not skills that are acquired naturally, but are learned. One of the factors that causes students' difficulty in writing is that students are less able to determine topics in writing. According to Amelia, Sukma, and Asma (2015), what can be done to involve students in finding resources in writing is to facilitate students to interact with the environment, so that students can actively participate in protecting the environment. Furthermore, according to Safitri and Sukma (2020), when writing use language that is easy to understand, and use topics related to certain environments.

One of the things that can inspire students when writing is to familiarize students with the environment. According to Sari, Hasanuddin, and Ramadhan (2013), in writing literary texts the writer can express his ideas creatively, where the work is adapted to environmental conditions. This shows that the writer cares about the environment around him. In line with that, according to Habibi, Sukirno, Sukma, Suriani, \& Putera, RF (2020), in learning materials to write narrative text, students can write it based on what is happening in their environment.

The existence of environmental material in Indonesian language learning, students can develop thinking skills. According to Fitri, Ramadhan, and Tamsin (2016), stated that with environmental material in Indonesian language learning, students will be invited to interact directly with the environment outside the classroom, so that students' intellectual abilities will develop. In line with that, according to Yantama, Ramadhan, and Afnita (2018), with problem-based learning in Indonesian, students can face challenges in life in an increasingly complex environment.

Furthermore, the environmental material contained in Indonesian language learning can develop students' imaginative power in writing. This is in line with Viodelf, Ramadhan, and Miaz (2018), the use of an environmental approach in learning to write is proven to improve students' writing skills. The environmental approach applied in Indonesian language learning can train students to observe 
what is happening in the surrounding environment, both inside the school environment and outside the school. Writing inspired by nature will motivate students to know everything about the natural environment.

Based on the problems described above, the authors conducted research on the relationship between Indonesian language learning and the environment. This research was conducted by making 10 questions in the form of aquestionnaire google form, in which the respondents in this study were students. The questionnaire was distributed to 30 students from UNP, UNAND, IAIN Bukittinggi, and UNRI. The results obtained from this study are as follows. The first statement is that environmental material is very important in Indonesian language learning, $66.7 \%$ agree, $33.3 \%$ strongly agree, $0 \%$ disagree, and $0 \%$ disagree. The second statement is that the attitude of protecting the environment is always applied during the learning process of Indonesian, 60\% agreed, 33.3\% strongly agreed, 6.7\% disagreed, and 0\% disagreed. Furthermore, the third statement is that in Indonesian language learning, environmental material is an interesting topic to study. $70 \%$ agreed, $26.7 \%$ strongly agreed, $3.3 \%$ disagreed, and $0 \%$ disagreed.

Furthermore, the fourth statement is that with the presence of environmental material in text learning, students can increase their knowledge of the environment, $63.3 \%$ agreed, 36.7\% strongly agreed, $0 \%$ disagreed, and $0 \%$ disagreed. The fifth statement is that in learning Indonesian, environmental materials can reduce student saturation in the teaching and learning process, $66.7 \%$ agree, $26.7 \%$ strongly agree, $6.6 \%$ disagree, and $0 \%$ disagree. The sixth statement is that environmental material in Indonesian language learning makes it easier for students to express ideas in writing, so that students can improve their writing skills $60 \%$ strongly agree, $46.7 \%$ agree, $3.3 \%$ disagree, and $0 \%$ disagree. agree. The seventh statement is that environmental preservation efforts can be found in Indonesian language learning reading texts. $60 \%$ agree, $33.3 \%$ strongly agree, $6.7 \%$ disagree and $0 \%$ disagree.

The eighth statement is that the teacher invites students to observe the community environment to make a descriptive text. $66.7 \%$ agree, $30 \%$ strongly agree, $3.3 \%$ disagree, and $0 \%$ disagree. The ninth statement reads, students are 
assigned to make an observation report about handling waste in their neighborhood, $56.7 \%$ agree, $33.3 \%$ agree, $10 \%$ disagree, and $0 \%$ disagree. The tenth statement, namely providing environmental material in Indonesian language learning is an effort to build ecological intelligence, $66.3 \%$ agree, $33.7 \%$ strongly agree, $0 \%$ disagree, and $0 \%$ disagree.

Based on the results of this research, it can be concluded that environmental material is very important to be applied in learning Indonesian. With the existence of environmental material in Indonesian language learning, students can build ecological intelligence. To apply these environmental materials, of course, we need teachers who can motivate students to love the environment. According to Zulhafizh, Ramadhan, and Atmazaki (2013), teachers play an important role in creating a conducive learning environment. In addition, according to Sukma, Ramadhan, and Indriani (2020), teachers are the most influential people in instilling environmental education from an early age. Teachers become role models for their students in the future, because student behavior is influenced by teacher behavior. 


\section{REFERENCES}

Amelia, Sukma,E., \& Asma. (2015). Pembelajaraan Menulis Laporan Percobaan Dengan Pendekatan Saintifik di Sekolah Dasar. In Prosiding Seminar Nasional Jurusan PGSD FIP UNP Tahun 2015 (Vol. 1, No. 1).

Fitri, Y., Ramadhan., \& Tamsin, A. C. (2016). Pengaruh Model Pembelajaran Kooperatif Tipe Think Talk Write Berbantuan Media Gambar terhadap Keterampilan Menulis Karangan Argumentasi Siswa Kelas X SMA Negeri 5 Padang. Pendidikan Bahasa Indonesia, 5(2), 548-554.

Habibi, M., Sukirno, T., Sukma, E., Suriani, A., \& Putera, R. F. (2020). Direct Writing Activity: A Strategy in Expanding Narrative Writing Skills for Elementary Schools. Universal Journal of Educational Research, 8(10), 4374-4383.

Ramadhan, S., Indriyani, V., Asri, Y., \& Sukma, E. (2020). Design of Learning Modules Writing Narrative Text Based on Project Based Learning (PjBL) by Using Mobile Devices. JPhCS, 1471(1), 012029.

Ramadhan, Sukma, E., \& Indriyani, V. (2019). Environmental education and disaster mitigation through language learning. In IOP Conference Series: Earth and Environmental Science (Vol. 314, No. 1, p. 012054).

Safitri, A., \& Sukma, E. (2020). Peningkatan Hasil Belajar Siswa pada Tema 3 Menggunakan Pendekatan Saintifik di Sekolah Dasar. Jurnal Pendidikan Tambusai, 4(3), 3132-3144.

Sari, M. K., Hasanuddin, W. S., \& Ramadhan, S. (2013). Majas Lokalitas dalam Kumpulan Sajak Mangkutak di Negeri Prosaliris Karya Rusli Marzuki Saria. Bahasa, Sastra, dan Pembelajaran, 1(2).

Sukma, E., Ramadhan, S., \& Indriyani, V. (2020). Integration of environmental education in elementary schools. In Journal of Physics: Conference Series (Vol. 1481, No. 1, p. 012136). IOP Publishing.

Viodelf, R., Ramadhan, \& Miaz, Y. (2018). Increasing writing skill of narrative and motivate students class IV primary school through environment approach. In International Conferences on Educational, Social Sciences and Technology (pp. 270-275). Fakultas Ilmu Pendidikan UNP. 
Yantama, S. P., Ramadhan, \& Afnita, A. (2018). Penerapan Pembelajaran Berbasis Masalah dalam Pembelajaran Teks Puisi untuk Siswa Kelas VIII SMP Negeri 4 Sungai Penuh. Pendidikan Bahasa Indonesia, 7(4), 104-114

Zulhafizh, Atmazaki, \& Ramadhan, S. (2013). Kontribusi sikap dan motivasi belajar siswa terhadap hasil belajar bahasa indonesia. Jurnal Bahasa, Sastra dan Pembelajaran, 1(2), 13-28. 
ATTACHMENT OF SUMMARY OF BUDGET RESULTS

"The Relationship of Indonesian Language Learning with the Environment"

\begin{tabular}{|c|c|c|c|c|c|}
\hline No & Question & $\begin{array}{l}\text { Strongly } \\
\text { agree }\end{array}$ & Agree & $\begin{array}{c}\text { Less } \\
\text { agree }\end{array}$ & $\begin{array}{l}\text { Dis- } \\
\text { agree }\end{array}$ \\
\hline 1. & $\begin{array}{l}\text { Environmental material is very in learning } \\
\text { Indonesian. }\end{array}$ & $33.3 \%$ & $66.7 \%$ & - & - \\
\hline 2. & $\begin{array}{l}\text { Attitudes to protect the environment are } \\
\text { always applied during the Indonesian } \\
\text { language learning process. }\end{array}$ & $33.3 \%$ & $60 \%$ & $6.7 \%$ & - \\
\hline 3. & $\begin{array}{l}\text { In Indonesian language learning, } \\
\text { environmental material is an interesting } \\
\text { topic to study. }\end{array}$ & $26.7 \%$ & $70 \%$ & $3.3 \%$ & - \\
\hline 4. & $\begin{array}{l}\text { The existence of environmental material in } \\
\text { text learning, students can increase their } \\
\text { knowledge of the environment. }\end{array}$ & $36.7 \%$ & $63.3 \%$ & - & - \\
\hline 5. & $\begin{array}{l}\text { In Indonesian language learning, } \\
\text { environmental materials can reduce student } \\
\text { saturation in the teaching and learning } \\
\text { process. }\end{array}$ & $26.7 \%$ & $66.7 \%$ & $6.6 \%$ & - \\
\hline 6. & $\begin{array}{l}\text { Environmental materials in Indonesian } \\
\text { language learning make it easier for students } \\
\text { to express ideas in writing, so that students } \\
\text { can improve their writing skills. }\end{array}$ & $60 \%$ & $46.7 \%$ & $3.3 \%$ & - \\
\hline 7. & $\begin{array}{l}\text { The seventh statement is an effort to } \\
\text { conserve the environment which can be } \\
\text { found in Indonesian reading texts. }\end{array}$ & $33.3 \%$ & $60 \%$ & $6.7 \%$ & - \\
\hline 8. & $\begin{array}{l}\text { Teacher invites students to observe the } \\
\text { community environment to make } \\
\text { descriptive texts. }\end{array}$ & $30 \%$ & $66,7 \%$ & $3,3 \%$ & - \\
\hline 9. & $\begin{array}{l}\text { Students are assigned to make an } \\
\text { observation report about the handling of } \\
\text { waste in their neighborhood. }\end{array}$ & & & & \\
\hline 10 & $\begin{array}{l}\text { Providing environmental materials in } \\
\text { Indonesian language learning is an effort to } \\
\text { build ecological intelligence. }\end{array}$ & $33.7 \%$ & $66.3 \%$ & - & - \\
\hline
\end{tabular}

